\title{
THE STUDY OF THE THREE-COMPONENT INTERACTION BETWEEN 1-ETHYL-1H-2,1-BENZOTHIAZIN-4(3H)-ONE 2,2-DIOXIDE, HETERYLCARBALDEHYDES AND ACTIVE METHYLENE NITRILES
}

\author{
D.A.Lega, V.P.Chernykh, L.A.Shemchuk
}

National University of Pharmacy

53, Pushkinska str., Kharkiv, 61002, Ukraine. E-mail: leonid.shemchuk@gmail.com

Key words: 2,1-benzothiazine 2,2-dioxide; heterylcarbaldehydes; active methylene nitriles; 4H-pyranes; threecomponent reaction; triethylammonium salts

Some peculiarities of the three-component interaction of 1-ethyl-1H-2,1-benzothiazin-4(3H)-one 2,2-dioxide with active methylene nitriles and heterylcarbaldehydes have been described in this article. It has been found that if malononitrile is used, the products of the three-component reaction are 2-amino-4-heteryl-3-cyano-6-ethyl-4,6dihydropyrano[3,2-c][2,1]benzothiazine 5,5-dioxides irrespective of the heteryl fragment nature in the initial aldehyde. When using ethyl cyanoacetate (as the active methylene nitrile) in the three-component interaction instead malononitrile the reaction lost its selectivity. In this case, depending on the heterylcarbaldehyde, three different types of products were obtained, namely 2-amino-3-alkoxycarbonyl-4-heteryl-4H-pyranes (for pyridine-3-, pyridine-4-carbaldehydes and furan-2-carbaldehyde), thriethylammonium salt of bis(1-ethyl-1H-2,1-benzothiazin-2,2dioxo-4-ol-3-yl)(2-thienyl)methane (for thiophen-2-carbaldehyde) or ethyl 2-cyano-3-(1H-indol-3-yl)acrylate (for indol-3-carbaldehyde). Formation of a stable triethylammonium salts was considered as the process competitive with formation of 2-amino-4H-pyranes. It has allowed to propose the modified mechanism of 2-amino-4H-pyranes formation. This mechanism includes the stage of forming triethylammonium salts of bis-adducts. According to this mechanism 2-amino-3-ethoxycarbonyl-4-(2-thienyl)-4H-pyrane without any impurity of bis-adduct could be selectively obtained using the three-component interaction. Triethylammonium salts of bis-adducts were obtained by direct interaction of 1-ethyl-1H-2,1-benzothiazin-4(3H)-one 2,2-dioxide with heterylcarbaldehydes in the presence of equimolar amounts of triethylamine. It has been shown that the three-component interaction of 1-ethyl-1H-2,1-benzothiazin-4(3H)-one 2,2-dioxide with active methylene nitriles and heterylcarbaldehydes is a more effective tool in order to obtain condensed 2-amino-4-heteryl-4H-pyranes compared to the stepwise approach.

ВИВЧЕННЯ ТРИКОМПОНЕНТНОЇ ВЗАЄМОДІЇ ЕТИЛ-1Н-2,1-БЕНЗОТІАЗИН-4(3Н)-ОН 2,2-ДІОКСИДУ 3 МЕТИЛЕНАКТИВНИМИ НІТРИЛАМИ ТА ГЕТЕРИЛКАРБАЛЬДЕГІДАМИ

Д.А.Лега, В.П.Черних, Л.А.Шемчук

Ключові слова: 2,1-бензотіазин 2,2-діоксид; гетерилкарбальдегіди; метиленактивні нітрили; 4Н-пірани; трикомпонентна взаємодія; триетиламонієві солі

Описані деякі особливості трикомпонентної взаємодії етил-1Н-2,1-бензотіазин-4(3Н)-он 2,2-діоксиду з метиленактивними нітрилами та гетерилкарбальдегідами. Встановлено, що у випадку використання малонодинітрилу продуктами трикомпонентної взаємодії були 2-аміно-4-гетерил-3-ціано-6-етил-4,6дигідропірано[3,2-с][2,1]бензотіазин 5,5-діоксиди незалежно від природи гетерильного фррагменту у вихідному альдегіді. При використанні в трикомпонентній взаємодії замість малонодинітрилу етилціаноацетату (в якості метиленактивного нітрилу) реакція втрачає свою селективність. У цьому випадку в залежності від природи гетерилкарбальдегіду було отримано три типи продуктів, а саме 2-аміно3-етоксикарбоніл-4-гетерил-4Н-пірани (для піридин-3-, піридин-4-карбальдегідів та фуран-2-карбальдегіду), триетиламонієва сіль біс(1-етил-1Н-2,1-бензотіазин-2,2-діоксо-4-ол-3-іл)(2-тієніл)метану (для тіофен-2-карбальдегіду) або етил-2-ціано-3-(1Н-індол-3-іл)акрилат (для індол-3-карбальдегіду). Утворення триетиламонієвих солей симетричних біс-адуктів з використанням гетерилкарбальдегідів спостерігалося нами вперше і його розглянуто як конкурентний до утворення 2-аміно-4Н-піранів процес. Це дозволило запропонувати модифрікований механізм формування 2-аміно-4Н-піранів, який включає стадію утворення триетиламонієвих солей біс-адуктів. Грунтуючись на запропонованому механізмі, ми змогли селективно одержати 2-аміно-3-етоксикарбоніл-4-(2-тієніл)-4Н-піран без домішок біс-адукту, використовуючи трикомпонентну взаємодію. Нами запропоновано спосіб одержання триетиламонієвих солей біс-адуктів прямою взаємодією 1-етил-1Н-2,1-бензотіазин-4(3Н)-он 2,2-діоксиду з гетерилкарбальдегідами в присутності еквімолярних кількостей триетиламіну. Було показано, що трикомпонентна взаємодія етил-1Н-2, 1-бензотіазин-4(3Н)-он 2,2-діоксиду з метиленактивними нітрилами та гетерилкарбальдегідами є більш ефективним інструментом синтезу конденсованих 2-аміно-4-гетерил-4Н-піранів у порівнянні з постадійним підходом. 
ИЗУЧЕНИЕ ТРЕХКОМПОНЕНТНОГО ВЗАИМОДЕЙСТВИЯ 1-ЭТИЛ-1Н-2,1-БЕНЗОТИАЗИН-4(3Н)-ОН
2,2-ДИОКСИДА С МЕТИЛЕНАКТИВНЫМИ НИТРИЛАМИ И ГЕТЕРИЛКАРБАЛЬДЕГИДАМИ

\section{Д.А.Лега, В.П.Черных, Л.А.Шемчук}

Ключевые слова: 2,1-бензотиазин 2,2-диоксид; гетерилкарбальдегиды; метиленактивные нитрилы; 4Н-пираны; трехкомпонентное взаимодействие; триэтиламмониевые соли

Описаны некоторые особенности трехкомпонентного взаимодействия 1-этил-1Н-2, 1-бензотиазин4(3Н)-он 2, 2-диоксида с метиленактивными нитрилами и гетерилкарбальдегидами. Установлено, что в случае использования малонодинитрила продуктами трехкомпонентного взаимодействия были 2амино-4-гетерил-3-циано-6-этил-4,6-дигидропирано[3,2-с][2,1]бензотиазин 5,5-диоксиды независимо от природы гетерильного фррагмента в исходном альдегиде. При использовании в трехкомпонентном взаимодействии вместо малонодинитрила этилцианоацетата (в качестве метиленактивного нитрила) реакция теряет свою селективность. В этом случае в зависимости от природы гетерилкарбальдегида были получены три типа продуктов, а именно 2-амино-3-алкоксикарбонил-4-гетерил-4Н-пираны (для пиридин-3-, пиридин-4-карбальдегидов и фруран-2-карбальдегида), триэтиламмониевая соль бис(1-этил1Н-2, 1-бензотиазин-2,2-диоксо-4-ол-3-ил)(2-тиенил)метана (для тиофен-2-карбальдегида) или этил2-циано-3-(1Н-индол-3-ил)акрилат (для индол-3-карбальдегида). Образование триэтиламмониевых солей симметричных бис-аддуктов рассматривалось как конкурентный образованию 2-амино-4Н-пиранов процесс. Это позволило предложить модифицированный механизм фрормирования 2-амино-4Н-пиранов, который включает стадию образования триэтиламмониевых солей бис-аддуктов. B coответствии с данным механизмом мы смогли селективно получить 2-амино-3-этоксикарбонил-4-(2-тиенил)4Н-пиран без какой-либо примеси бис-аддукта, используя трехкомпонентное взаимодействие. Триэтиламмониевые соли бис-аддуктов были получены прямым взаимодействием 1-этил-1Н-2,1-бензотиазин4(3Н)-он 2,2-диоксида с гетерилкарбальдегидами в присутствии эквимолярных количеств триэтиламина. Было показано, что трехкомпонентное взаимодействие 1-этил-1Н-2,1-бензотиазин-4(3Н)-он 2,2-диоксида с метиленактивными нитрилами и гетерилкарбальдегидами является более эфффективным инструментом синтеза конденсированных 2-амино-4-гетерил-4Н-пиранов по сравнению с постадийным подходом.

Currently, a variety of new compounds are continuously synthesized due to design of novel biologically active substances. In this regard, derivatives of benzothiazinone S,S-dioxide occupy a special place since they are very promising compounds for creating new drugs. This is associated with their fairly wide range of biological activities. Recently the literature data indicate the increased interest towards such derivatives; in particular by the research groups of pharmaceutical companies [1, 2, 3].

It is possible that there are 10 structural isomers of benzothiazinone S,S-dioxides [4]. Among them we focused on $1 H$-2,1-benzothiazin-4(3H)-one 2,2-dioxides (Fig. 1) because of the insufficient studies of their chemical properties. They have not been studied in multicomponent reactions, and therefore, they are a new synthon for such interactions.

It is well known that most of sulfonamides are biologically useful compounds $[5,6,7,8]$. Specifically, the cyclic sulfonamides (sultams) are important therapeutic and chiral agents [9]. This group includes derivatives of 2,1-benzothiazine (benzosultams), the important class of heterocyclic compounds, due to the fact that derivatives of this heterocyclic system possess the versatile range of biological activities. For example, derivatives of 3,4-dihydro-2,1-benzothiazi-<smiles>[R]N1c2ccccc2C(=O)CS1(=O)=O</smiles>

Fig. 1. The general formula for 1-R-1H-2,1-benzothiazin-4(3H)-one 2,2-dioxides. ne 2,2-dioxide have proven their effectiveness against heart diseases as the inhibitors of lipogenase (Fig. 2) [10].

Some $1 H$-2,1-benzothiazine 2,2-dioxide derivatives have been recently reported to have biological activities such as IL-8 receptor antagonists, 5-HT receptor antagonists [11], factor Xa inhibitory [12], the antiviral activity (reverse transcriptase inhibitors) [13] and the antibacterial activity [14] (Fig. 3) although the reports on the biological relevance of the corresponding 4-oxo derivatives (Fig. 1) as a core structure are rare.

The relevance of studying $1 H$-2,1-benzothiazin$4(3 H)$-one 2,2-dioxides is also caused by their bioisosteric relationship to 2,3-dihydro- $4 H$-1,2-benzothiazin-4-one 1,1-dioxide, which is the base of commercially successful nonsteroidal anti-inflammatory drugs (NSAIDs), such as Piroxicam ${ }^{\circledR}$, Droxicam ${ }^{\circledR}$, Meloxicam ${ }^{\circledR}$ and its heteroanologues - Tenoxicam ${ }^{\circledR}$ and Lornoxi$\mathrm{cam}^{\circledR}$. It has been shown that some 3-carbamoyl derivatives of $1 H$-2,1-benzothiazin-4(3H)-one 2,2-dioxide exhibit much higher analgesic activity than Piroxicam ${ }^{\circledR}$ and Meloxicam ${ }^{\circledR}$ [15].

Therefore, chemical transformations of $1 H$-2,1-benzothiazin-4(3H)-one 2,2-dioxide core is a promising route to search new pharmacologically useful compounds.

$1 H$-2,1-Benzothiazin-4(3H)-one 2,2-dioxide is an analogue of cyclic 1,3-dicarbonyl compounds (Fig. 4).

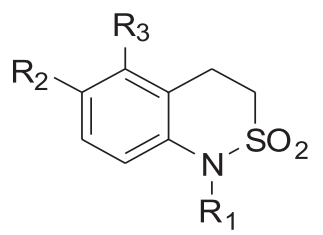

$\mathrm{R}_{1}=\mathrm{H}, \mathrm{Bn}$

$\mathrm{R}_{2}=\mathrm{H}$, Piperazinyl

$\mathrm{R}_{3}=\mathrm{H}$, Alkoxy, Hydroxy

Fig. 2. The general formula for derivatives of 2,1-benzothiazine 2,2-dioxide - inhibitors of lipogenase. 


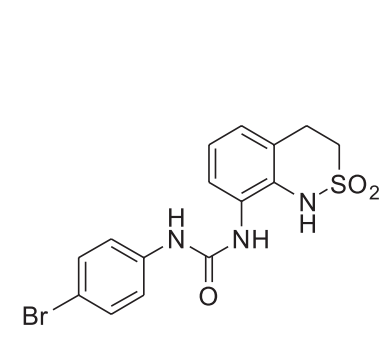

antagonist of IL-8 receptor

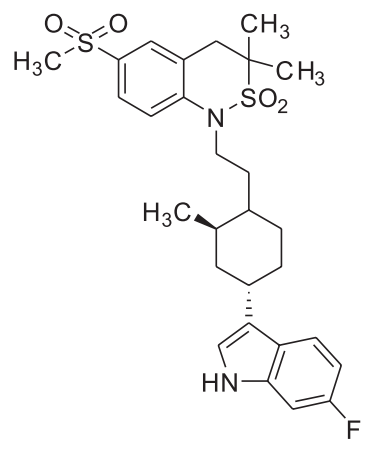

antagonist of $5-\mathrm{HT}$ receptor<smiles>N=C(N)c1ccc2ccc(CN3c4ccc(OC5CCN(C(=N)N)CC5)cc4C=C(C(=O)O)S3(=O)=O)cc2c1</smiles>

inhibitor of $\mathrm{Xa}$ factor

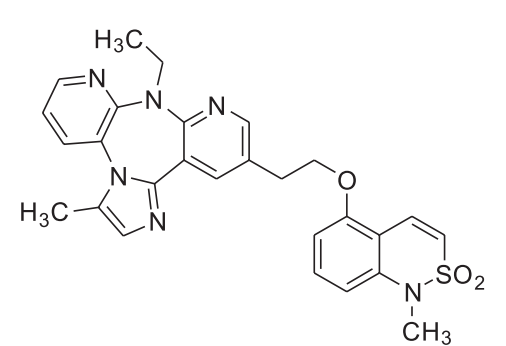

antiviral<smiles>CC1[O+]N(C2CC2)c2cc(N3CCN(C)CC3)c(N)cc2C1=O</smiles>

antibacterial

Fig. 3. Some examples of biologically active $1 H$-2,1-benzothiazine 2,2-dioxides.
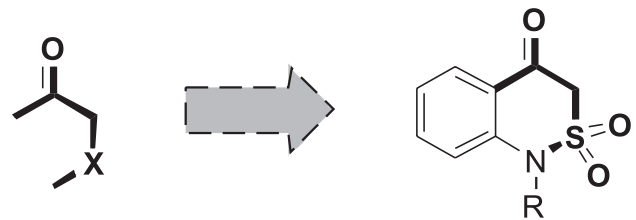

Fig. 4. 1H-2,1-Benzothiazin-4(3H)-one 2,2-dioxide is an analogue of cyclic 1,3-dicarbonyl compounds.

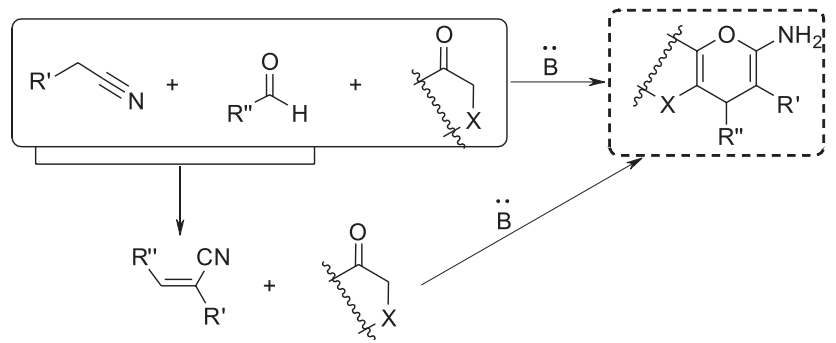

Scheme 1. Two approaches toward 2-amino-3-R'-4-R"-4H-pyranes.

It also contains the active methylene group. This provides great opportunities for construction new condensed heterocyclic systems on its base.

In contrast to the latter, $1 H-2,1$-benzothiazin- 4 $(3 H)$-one 2,2-dioxide is characterized by special structural and reactivity features. In spite of the expected properties of ketones, $1 H$-2,1-benzothiazin-4(3H)-one 2,2-dioxide can not be reduced to the alcohol either by catalytic reduction (hydrogenation in various solvents using platinum or nickel catalysts at various temperatures and pressures) or chemical means (borohydride, lithium aluminum hydride, or sodium and alcohol). It also fails to form oximes and semicarbazones, and it does not form enamines in reactions with the secondary amines $[4,16]$.

1H-2,1-benzothiazin-4(3H)-one 2,2-dioxide, which is unsubstituted in position 3 , exists mainly in the keto form. By contrast, its carbonyl analogue - quinolin$2,4(1 H, 3 H)$-dione - exists almost solely in the enol form [16]. However, the carbonyl group of $1 H$-2,1-benzothiazin-4(3H)-one 2,2-dioxide is characterized by a high propensity for enolization introducing alkyl or acyl groups into position 3 . This fact was used to construct a fused heterocyclic system on its base $[17,18]$. We used this property in order to synthesize a new heterocyclic system of 2-amino-3-R-6-ethyl-4,6-dihydropyrano[3,2-c][2,1]benzothiazine 5,5-dioxide spirocondensed with the 2-oxindole core. The target compounds were obtained using the three-component interaction of $1 H$-2,1-benzothiazin-4(3H)-one 2,2-dioxide with isatins and active methylene nitriles [19]. This article was the first one dedicated to the multicomponent reactions of $1 H$-2,1-benzothiazin-4(3H)-one 2,2-dioxide.

According to the literature such three-component interaction of 1,3-dicarbonyl compounds with aldehydes and active methylene nitriles leads to formation of the corresponding 2-amino-3-R'-4-R"-4H-pyranes (Scheme 1). The mechanism of this coupling is based on a domino Knoevenagel/Michael/hetero-ThorpeZiegler cyclization sequence followed by enamineamine tautomerism [20]. It is possible to carry out a two-step synthesis of 2-amino-3-R'-4-R"-4H-pyranes using the corresponding Knoevenagel condensation products $-\alpha, \beta$-unsaturated nitriles. This approach has its disadvantages since the intermediate unsaturated nitriles in most cases are toxic and lachrymatory agents $[21,22]$ (Scheme 1).

Therefore, in continuation of our research the treecomponent interaction of 1-ethyl-1H-2,1-benzothiazin-4(3H)-one 2,2-dioxide with heterylcarbaldehydes and active methylene nitriles was studied in order to synthesize fused 2-amino-4H-pyranes. 

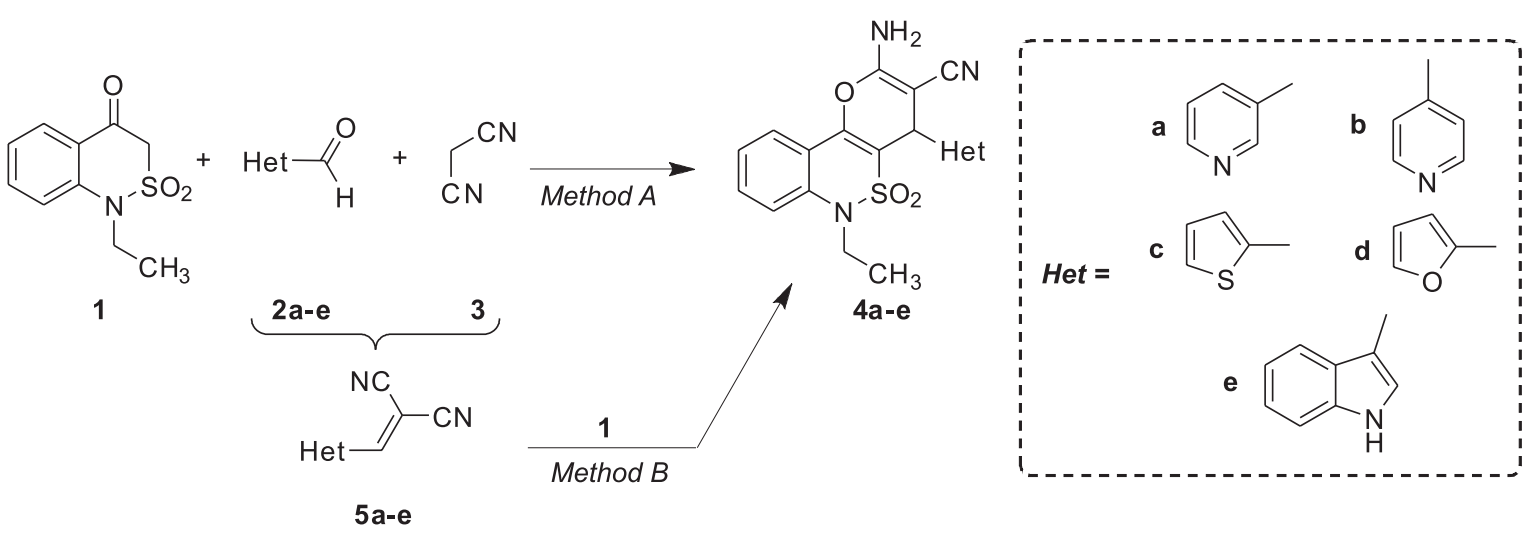

Scheme 2. The formation of target 2-amino-3-cyano-4H-pyranes (4a-e).

\section{Results and Discussion}

The representatives of electron-rich (thiophen-2carbaldehyde, furfural and indol-3-carbaldehyde) and electron-deficient heterocycles (2-, 3-, 4-pyridincarbaldehydes) were used as heterylcarbaldehydes.

The first stage of our studies was dedicated to the use of malononitrile as an active methylene nitrile in the three-component one-pot interaction.

As the result of the experiments conducted it has been found that the three-component reaction of 1ethyl-1H-2,1-benzothiazin-4(3H)-one 2,2-dioxide (1) with heterylcarbaldehydes (2a-e) and malononitrile (3) leads to formation of the target 2-amino-3-cyano4H-pyranes (4a-e) (Scheme 2, Method A) in high or excellent yields in all cases, except pyridine-2-carbaldehyde (Table 1).

As the result of high reactivity of pyridine-3-carbaldehyde (4a) and pyridine-4-carbaldehyde (4b) the interaction in these cases proceeded in ethanol at the room temperature for $10 \mathrm{~min}$ with almost quantitative yields of the target products $(\mathbf{4 a}, \mathbf{b})$ (Table 1 , Method A). In general, such interactions need a base as a catalyst of the reaction. When pyridinecarbaldehydes $(\mathbf{4 a}, \mathbf{b})$ are used, it is not necessary to use the base, and it can be explained by autocatalytic effect of the pyridine ring.

Table 1

\begin{tabular}{|c|c|c|c|c|}
\hline \multirow[b]{2}{*}{ 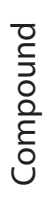 } & \multirow[b]{2}{*}{ Heteryl } & \multirow[b]{2}{*}{ Conditions } & \multicolumn{2}{|c|}{ Yield, \% } \\
\hline & & & $\begin{array}{l}\varangle \\
0 \\
0 \\
1 \\
+ \\
\sum\end{array}$ & 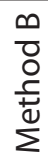 \\
\hline $4 a$ & 3-pyridyl & $\mathrm{EtOH}, \mathrm{rt}, 10 \mathrm{~min}$ & 98 & 81 \\
\hline $4 b$ & 4-pyridyl & $\mathrm{EtOH}, \mathrm{rt}, 10 \mathrm{~min}$ & 95 & 74 \\
\hline $4 c$ & 2-thienyl & $\begin{array}{c}\mathrm{EtOH}, \mathrm{Et}_{3} \mathrm{~N} \text { (cat.), } \\
\text { reflux, } 2 \mathrm{~h}\end{array}$ & 83 & 72 \\
\hline $4 d$ & 2-furyl & $\begin{array}{c}\mathrm{EtOH}, \mathrm{Et}_{3} \mathrm{~N} \text { (cat.), } \\
50^{\circ} \mathrm{C}, 10 \mathrm{~h}\end{array}$ & 63 & 36 \\
\hline $4 \mathrm{e}$ & 3-indolyl & $\begin{array}{l}\mathrm{EtOH}, \mathrm{Et}_{3} \mathrm{~N} \text { (cat.), } \\
\text { reflux, } 13 \mathrm{~h}\end{array}$ & 53 & 41 \\
\hline
\end{tabular}

A gradual decrease in the yields of the target pyranes (4) and a gradual increase of the reaction time was observed in the case of thiophene-2-carbaldehyde (2c), furan-2-carbaldehyde (2d) and indol-3-carbaldehyde (2e). This can happen because of the influence of the electron-rich heterocyclic system on the activity of the aldehyde group. In this case, the interaction was carried out in refluxed ethanol for 2-13 $\mathrm{h}$ in the presence of the catalytic amounts of triethylamine (Table 1, Method A). When the reaction mixtures were refluxed for less time than required, the reaction was not completed and the target 2 -amino$4 H$-pyranes (4c-e) were contaminated with the intermediate 2-cyano-3-heterylacrylonitriles. The use of the equimolar amounts of triethylamine did not lead to increase of the interaction efficiency and decrease of the reaction time.

According to Scheme 1 the stepwise approach towards 2 -amino- $4 H$-pyranes (4a-e) with the preliminary obtaining of 2-cyano-3-heterylacrylonitriles (5a-e) was also performed (Scheme 2, Method B). It was found that this route resulted in the lower yields of 2amino-4H-pyranes (4a-e) compared to those obtained by MCRs (Table 1, Method B). The summarized results confirm the preferred applicability of the multicomponent format for the synthesis of 2-amino- $4 \mathrm{H}$ pyranes (4a-e).

The products (4a-e) precipitated from the reaction mixture were recrystallized from ethanol.

Our attempts to use pyridine-2-carbaldehyde in such three-component interaction (Scheme 2, Method A) under conditions common for pyridinecarbaldehydes $(\mathbf{2 a}, \mathbf{b})(\mathrm{EtOH}, \mathrm{rt}, 10 \mathrm{~min})$ led to isolation of an unidentified black coal-like product. Variation of the solvents used, thermal conditions, the reaction time, as well as the presence or absence of a catalyst did not give any positive results.

The next stage of our studies was the use of ethyl cyanoacetate (6) as the active methylene nitrile in this three-component interaction. However, the initial experiments showed the significant decrease of the reaction selectivity (Scheme 3, Method A). 


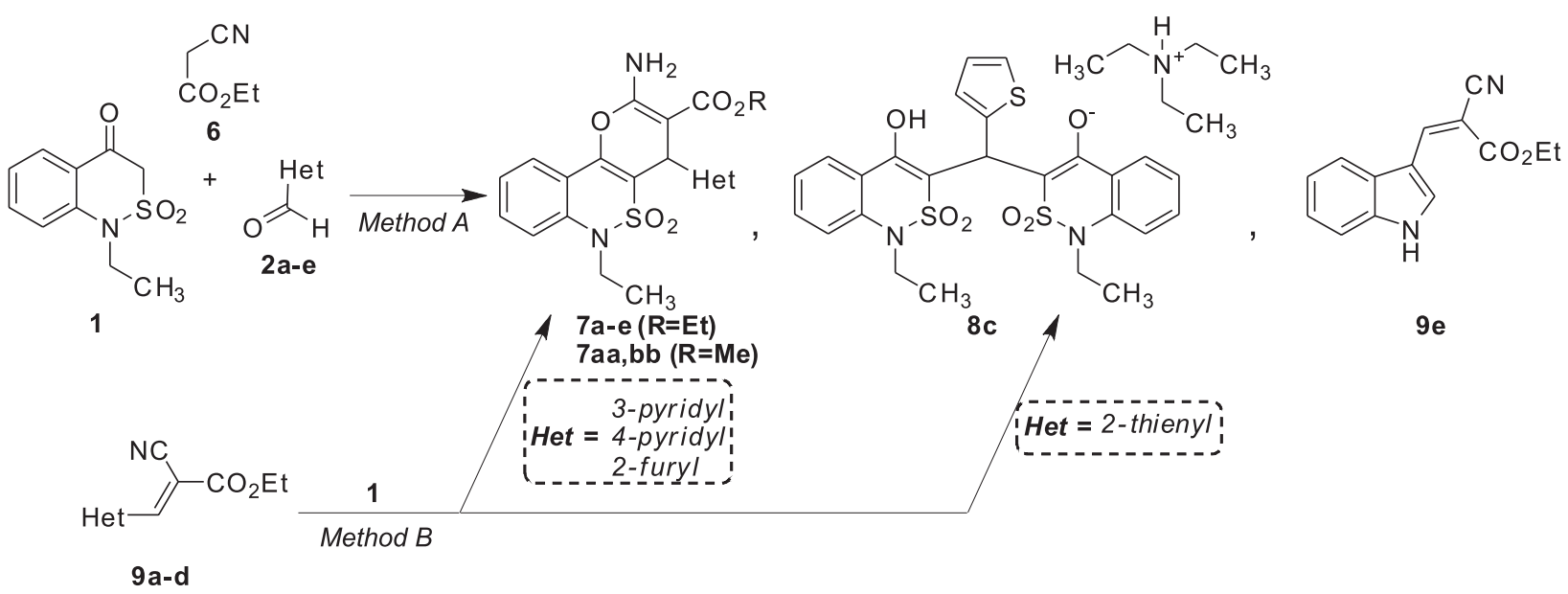

Scheme 3. The usage of ethyl cyanoacetate (6) as the active methylene nitrile in this three-component interaction.<smiles>CCN1C(=O)C(=Cc2cccs2)C(=O)c2ccccc21</smiles>

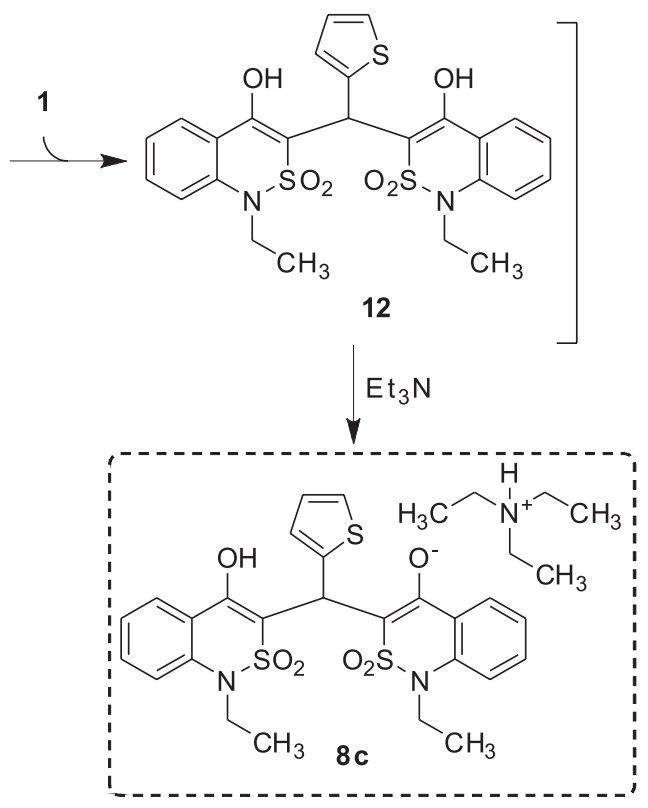

Scheme 4. A presumable mechanism for formation of the salt (8c).

The target 2-amino-4H-pyranes (7) were obtained only for pyridine-3-carbaldehyde (2a) and pyridine4-carbaldehyde ( $\mathbf{2 b}$ ), and also for furan-2-carbaldehyde (2d).

Due to the lower reactivity of ethyl cyanoacetate compared to malononitrile the three-component interaction (Scheme 3, Method A) involving pyridinecarbaldehydes $(\mathbf{2 a}, \mathbf{b})$ needed the catalytic amounts of triethylamine as the base and heating. The interaction in these cases was carried out in refluxing ethanol for $7 \mathrm{~h}$. If methanol was used as a solvent, the interaction was accompanied by the transesterification and the products obtained were the corresponding methyl esters - 2-amino-3-methoxycarbonyl-4H-pyranes (7aa and $\mathbf{7 b b}$ ) (Scheme 3, Method A).

To obtain 2-amino- $4 H$-pyrane $(\mathbf{7 d})$ in the case of furan-2-carbaldehyde (2d) it was necessary to reflux the reaction mixture in ethanol for $10 \mathrm{~h}$ and use equimolar amounts of 4-dimethylaminopyridine, as a catalyst instead triethylamine (in the case of triethylamine any product of the three-component reaction was not isolated).
For indole-3-carbaldehyde (2e) the reaction was completed on formation of ethyl 3-(3-indolyl)-2-cyanoacrylate (9e) (Scheme 2, Method A). In spite of our attempts to prolong the reaction time (up to $24 \mathrm{~h}$ ) we failed to obtain 2-amino- $4 H$-pyranes. This can be explained by the low activity of $(\mathbf{9 e})$ in the Michael addition reaction towards 1 -ethyl-1H-2,1-benzothiazin4(3H)-one 2,2-dioxide (1).

When thiophene-2-carbaldehyde (2c) was used, the three-component reaction led to formation of the unexpected bis-adduct - the thriethylammonium salt of bis(1-ethyl-1H-2,1-benzothiazin-2,2-dioxo-4-ol-3-yl) (2-thienyl)methane (8c) (Scheme 2, Method A). To avoid formation of this salt and obtain 2-amino- $4 \mathrm{H}$ pyrane (7c) we tried to use stepwise approach (Scheme 3, Method B). However, contrary to our expectations, this stepwise format resulted in formation of bis-adduct (8c) too. In order to explain this result, we have to assume that Michael adduct (10c) initially formed (Scheme 4) does not undergo the intramolecular hetero-Thorpe-Ziegler cyclization. It eliminates the mo- 
Table 2

Yields of products of three-component reactions with ethyl cyanoacetate (Scheme 3)

\begin{tabular}{|c|c|c|c|c|c|}
\hline \multirow{2}{*}{$\begin{array}{l}\frac{0}{0} \\
\frac{\frac{1}{d}}{\frac{0}{2}} \\
\frac{0}{2}\end{array}$} & \multirow[b]{2}{*}{ Heteryl } & \multirow[b]{2}{*}{ Conditions } & \multicolumn{2}{|c|}{$\begin{array}{l}\text { Yield } \\
\text { of } 7, \%\end{array}$} & \multirow[b]{2}{*}{$\begin{array}{c}\text { Yield } \\
\text { of } 8^{*}, \\
\%\end{array}$} \\
\hline & & & $\begin{array}{l}\varangle \\
0 \\
0 \\
\frac{1}{1} \\
\frac{d}{2}\end{array}$ & $\begin{array}{l}\infty \\
0 \\
0 \\
\frac{0}{ \pm} \\
\sum \\
\sum\end{array}$ & \\
\hline $2 a$ & 3-pyridyl & $\begin{array}{c}\mathrm{EtOH}_{,} \mathrm{Et}_{3} \mathrm{~N} \text { (cat.), } \\
\text { reflux, } 7 \mathrm{~h}\end{array}$ & 47 & 35 & - \\
\hline $2 b$ & 4-pyridyl & $\begin{array}{c}\mathrm{EtOH}, \mathrm{Et}_{3} \mathrm{~N} \text { (cat.), } \\
\text { reflux, } 7 \mathrm{~h}\end{array}$ & 52 & 28 & - \\
\hline \multirow{3}{*}{$2 c$} & \multirow{3}{*}{ 2-thienyl } & $\begin{array}{c}\mathrm{EtOH}, \mathrm{Et}_{3} \mathrm{~N} \text { (cat.), } \\
1 \text { equiv of }(\mathbf{6}), \\
\text { reflux, } 8 \mathrm{~h}\end{array}$ & - & - & $\begin{array}{c}37^{* * *} \\
\left(49^{* * *}\right)\end{array}$ \\
\hline & & $\begin{array}{c}\mathrm{EtOH} \mathrm{Et}_{3} \mathrm{~N} \text { (cat.), } \\
3 \text { equiv of }(\mathbf{6}), \\
\text { reflux, } 8 \mathrm{~h}\end{array}$ & $29^{* *}$ & - & $21^{* *}$ \\
\hline & & $\begin{array}{c}\mathrm{EtOH}, \mathrm{Et}_{3} \mathrm{~N} \text { (cat.), } \\
7 \text { equiv of }(\mathbf{6}), \\
\text { reflux, } 8 \mathrm{~h}\end{array}$ & 43 & - & - \\
\hline $2 d$ & 2-furyl & $\begin{array}{l}\text { EtOH, DMAP, } \\
\text { reflux, } 10 \mathrm{~h}\end{array}$ & 41 & 21 & - \\
\hline
\end{tabular}

* - For the three-component reaction with thiophen-2-carbaldehyde; ** - Confirmed by ${ }^{1} \mathrm{H}$ NMR spectra of the precipitate isolated without purification as the intensity ratio of proton in position 4 of the $4 \mathrm{H}$-pyran ring and the methyne moiety proton of a bis-derivative. Yields of compound (8) were calculated based on 2.0 eq. of compound (1);*** - For the stepwise synthesis use (9c) (Scheme 3, Method B).

lecule of ethyl cyanoacetate (6) and forms enone (11c). The last one acting as a Michael acceptor reacts with another molecule of 1-ethyl-1H-2,1-benzothiazin-4 $(3 \mathrm{H}$ )-one 2,2-dioxide (1) with formation of dienol (12). Intermediate (12) possesses the increased $\mathrm{OH}$-acidic properties due to the electron-withdrawing effect of $\mathrm{SO}_{2}$-groups. Moreover, in product $(\mathbf{8 c})$ formation of the intramolecular hydrogen bond, which stabilizes the structure of enolate anion, is possible. As the result, intermediate (12) reacts with triethylamine giving triethylammonium salt (8c). We have not found any literature data about formation of such bis-adducts salts that are similar to $(\mathbf{8 c})$. At the same time there are many examples of symmetrical bis-adducts as dienols, which can be easily obtained by the interaction of different 1,3-dicarbonyl compounds with aldehydes under the base catalysis [23, 24].

Enone (11c) is the key intermediate in the mechanism (Scheme 4) since it can be transformed either into bis-adduct (8c) or into the target 2-amino- $4 \mathrm{H}$ pyrane (7c) (through formation of Michael adduct (10c)). These processes are competitive and each can prevail under certain conditions. According to the literature data about reversibility of enone (11c) formation we tried to direct the transformation of enone $(\mathbf{1 1 c})$ towards 2 -amino-4H-pyran (7c) using an excess of ethyl
Yields for the compounds (8a-e) synthesized by direct interaction of (1) with (2)

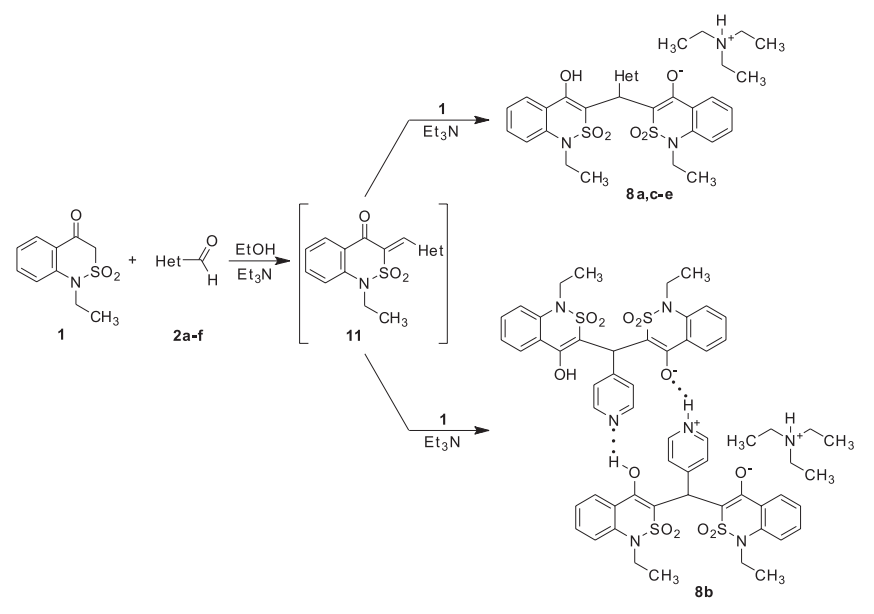

\begin{tabular}{|c|c|c|c|}
\hline 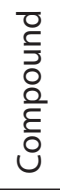 & Heteryl & Conditions & $\frac{0}{\frac{0}{0}} \frac{0}{2}$ \\
\hline $8 a$ & 3-pyridyl & $\mathrm{EtOH}, \mathrm{Et}_{3} \mathrm{~N}, \mathrm{rt}$ & 47 \\
\hline $8 b$ & 4-pyridyl & $\begin{array}{c}\mathrm{EtOH}, \mathrm{Et}_{3} \mathrm{~N} \\
70^{\circ} \mathrm{C}, 2 \mathrm{~h}\end{array}$ & 52 \\
\hline $8 c$ & 2-thienyl & $\mathrm{EtOH}, \mathrm{Et}_{3} \mathrm{~N}, \mathrm{rt}$ & 73 \\
\hline $8 d$ & 2-furyl & $\mathrm{EtOH}, \mathrm{Et}_{3} \mathrm{~N}, \mathrm{rt}$ & 54 \\
\hline $8 e$ & 3-indolyl & $\begin{array}{c}\mathrm{EtOH}, \mathrm{Et}_{3} \mathrm{~N}, \\
70^{\circ} \mathrm{C}, 12 \mathrm{~h}\end{array}$ & 35 \\
\hline
\end{tabular}

cyanoacetate (6). When 3.0 equiv of (6) was used, the isolated mixture contained the target 2 -amino- $4 \mathrm{H}$ pyrane (7c) and bis-adduct $(\mathbf{8 c})$ in the molar ratio of 1:0.4 (based on the ${ }^{1} \mathrm{H}$ NMR spectroscopy data). Application of 7.0 equiv of (6) allowed to obtain compound (7c) in the yield of 53\% without any impurity of bis-adduct (8c).

As in the case of malononitrile (3), the use of pyridine-2-carbaldehyde in the three-component reaction with (1) and (6) led to isolation of an unidentified black coal-like product.

We also attempted to obtain the triethylammonium salts of bis-adducts by direct interaction of 1-ethyl$1 H$-2,1-benzothiazin-4(3H)-one 2,2-dioxide (1) with heterylcarbaldehydes (2). This interaction may proceed through formation of highly reactive enone (11) (Table 3). The last one, as a Michael acceptor, reacts in the presence of triethylamine with the second molecule of (1) resulting in formation of salts (8). The reaction, in general, is carried out by the interaction of compounds (1) and (2) (the molar ratio-2:1) in ethanol in the presence of equimolar amounts of triethylamine. When aldehydes $(\mathbf{2} \mathbf{b}, \mathbf{e})$ were used, the reaction was carried out under conditions of heating (without heating the reaction was not complete as it was confirmed by ${ }^{1} \mathrm{H}$ NMR-spectra). It allowed to 


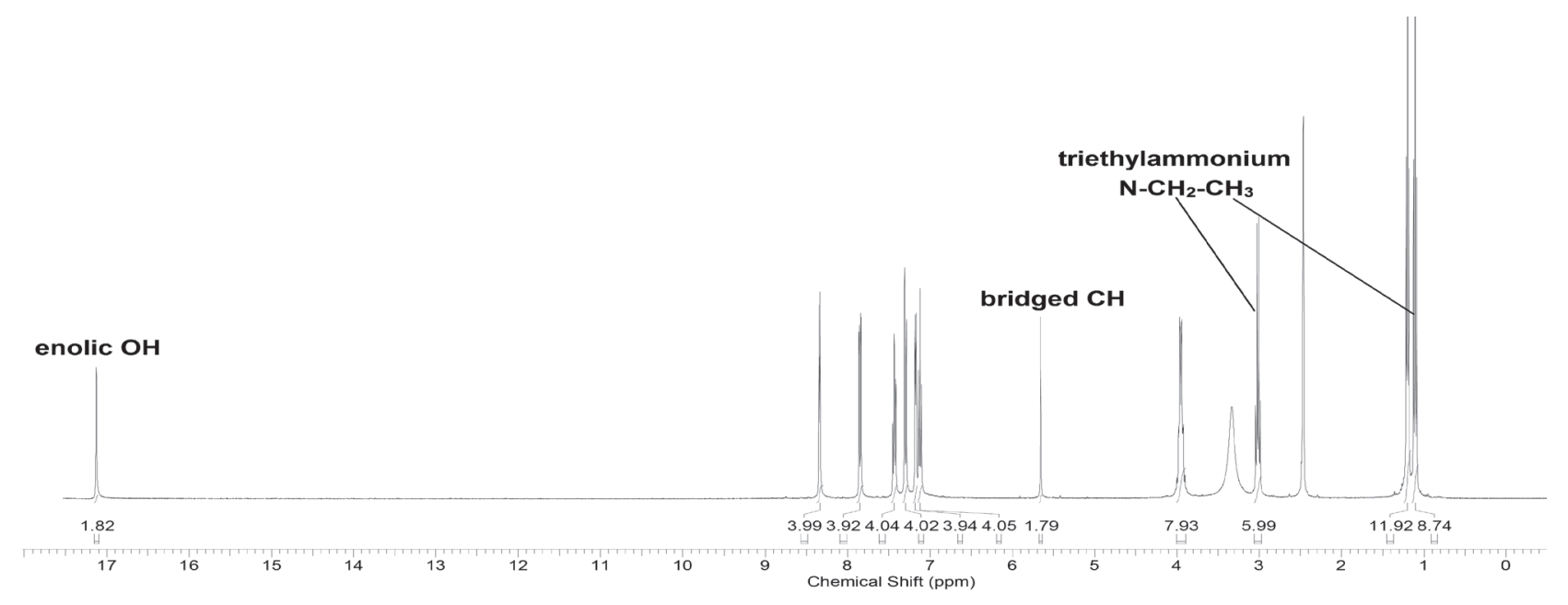

Fig. 5. The ${ }^{1} \mathrm{H}$ NMR-spectrum of $(\mathbf{8 b})$.

obtain the corresponding triethylammonium salts (8a-e) (Table 3).

If aldehyde (2b) was used in this reaction, triethylammonium salt (8b) was obtained. In the ${ }^{1} \mathrm{H}$ NMR spectrum of (8b) (Fig. 5) protons corresponding to two enolic $\mathrm{OH}$-groups, two bridged methyne $\mathrm{CH}$-groups and the triethylammonium cation can be observed. According to this spectrum the molar ratio of the enolate anion and the triethylammonium cation is 2:1. Conducting the reaction in the presence of more than equimolar amounts of triethylamine led to the same result.

In accordance with these data we suggested that compound (8b) represents a peculiar double salt, in which triethylammonium and pyridinium cations are present. This is more interesting due to the less basic properties of the pyridine ring compared to triethylamine. Such "dimeric" structure can be stable due to the presence of hydrogen bonds, but it is required the additional study to determine the structure of $(\mathbf{8 b})$. The yields of the compounds (8a-e) synthesized are presented in Table 3.

The structures of all compounds synthesized were confirmed by the data of ${ }^{1} \mathrm{H}$ NMR spectroscopy and elemental analysis. ${ }^{1} \mathrm{H}$ NMR-spectra of compounds (4) are characterized by the presence of the narrow highintensity singlet in position 4 of the $4 \mathrm{H}$-pyran ring in the range of 4.78-5.06 ppm, as well as the singlet of the 2 -amino group, which can be observed in the range of 7.23-7.47 ppm. In ${ }^{1} \mathrm{H}$ NMR-spectra of compounds (7) the singlet in position 4 of the $4 \mathrm{H}$-pyran ring can be found in the region of 4.83-5.17 ppm, the signal of the 2 -amino group is situated in the range of 7.80-7.90 ppm. The ${ }^{1} \mathrm{H}$ NMR-spectra of bis-adducts $(8)$ are characterized by the presence of the singlet of the benzothiazine OH-group at 17.13-17.49 ppm and the CH-group bridge at 5.62-5.91 ppm. The signals of the triethylammonium $\mathrm{NH}$-group and pyridinium of the $\mathrm{NH}$-group (for $\mathbf{8 b}$ ) are not found in the ${ }^{1} \mathrm{H}$ NMR-spectra probably due to the fast deutero exchange.

\section{Experimental Part}

The starting aldehydes (2a-f) and active methylene nitriles were obtained from commercial sources and purified before using; aldehydes (2a-d,f) were distilled under reduced pressure, aldehyde (2e) was recrystallized from methanol. The starting 1-ethyl- $1 \mathrm{H}-2,1-$ benzothiazin-4(3H)-one 2,2-dioxide was obtained according to the procedure previously described. Arylidenes (5a-e) and (9a-d) were prepared via Knoevenagel condensation of the corresponding heterylcarbaldehydes (2a-e) and active methylene nitriles (3) or (6) in the presence of a base as was reported [25]. Melting points were determined on a Gallenkamp melting point apparatus, MFB-595 model, in open capillary tubes. ${ }^{1} \mathrm{H}$ NMR-spectra were recorded on a Bruker AMX 500 spectrometer using DMSO- $\mathrm{d}_{6}$ as a solvent, and TMS as an internal standard. Elemental analyses were carried out using a Carlo Erba CHNS-O EA 1108 analyzer.

The general procedure for the synthesis of 2-amino4-(pyridyl)-3-cyano-6-ethyl-4,6-dihydropyrano[3,2-c] [2,1] benzothiazine 5,5-dioxides (4a,b).

Method A. The three-component one-pot procedure. Mix the solution of 1-ethyl-1H-2,1-benzothiazin-4(3H)-one 2,2-dioxide (1) ( $0.225 \mathrm{~g}, 0.001 \mathrm{Mol})$, malononitrile (3) $(0.066 \mathrm{~g}, 0.001 \mathrm{Mol})$ and the corresponding pyridinecarbaldehydes $(2 \mathbf{2 a}, \mathbf{b})(0.001 \mathrm{Mol})$ in ethanol $(5-10 \mathrm{~mL})$ for $10 \mathrm{~min}$ at the room temperature. A precipitate is formed in a few minutes after the beginning of mixing. Filter the resulting precipitates of $(\mathbf{4 a}, \mathbf{b})$, wash with ethanol, then dry on air and recrystallize from ethanol.

Method B. The synthesis using intermediate acrylonitriles (5a,b). Mix the solution of 1-ethyl-1H-2,1-benzothiazin-4(3H)-one 2,2-dioxide $1(0.225 \mathrm{~g}, 0.001 \mathrm{Mol})$ and acrylonitriles $(\mathbf{5 a}, \mathbf{b})(0.001 \mathrm{Mol})$ in ethanol $(5-10 \mathrm{~mL})$ for $10 \mathrm{~min}$. The resulting reaction mixtures are treated as mentioned in Method $A$.

The yields for the compounds $(\mathbf{4 a}, \mathbf{b})$ synthesized are presented in Table 1. 
2-Amino-4-(3-pyridyl)-3-cyano-6-ethyl-4,6-dihydropyrano[3,2-c][2,1] benzothiazine 5,5-dioxide (4a). A white powder. M. p. $-248-250^{\circ} \mathrm{C}$ (decomp.) (from EtOH). Anal. Calcd for $\mathrm{C}_{19} \mathrm{H}_{16} \mathrm{~N}_{4} \mathrm{O}_{3} \mathrm{~S}$ : C, 59.99; $\mathrm{H}, 4.24$; N, 14.73; S, 8.43. Found: C, 60.38; H, 4.02; N, 14.35; $\mathrm{S}$, 8.34. ${ }^{1} \mathrm{H}$ NMR (500 MHz, DMSO-d 6 ): $\delta(\mathrm{ppm}) 8.49$ (d, $J=1.92 \mathrm{~Hz}, 1 \mathrm{H}), 8.45$ (d, $J=3.41 \mathrm{~Hz}, 1 \mathrm{H}), 7.93$ (d, $J=7.67 \mathrm{~Hz}, 1 \mathrm{H}), 7.60-7.72(\mathrm{~m}, 2 \mathrm{H}), 7.54(\mathrm{~d}, J=8.31$ $\mathrm{Hz}, 1 \mathrm{H}), 7.29-7.48(\mathrm{~m}, 4 \mathrm{H}), 4.79(\mathrm{~s}, 1 \mathrm{H}), 3.87$ (q, $J=6.96$ $\mathrm{Hz}, 2 \mathrm{H}), 1.01(\mathrm{t}, J=7.03 \mathrm{~Hz}, 3 \mathrm{H})$.

2-Amino-4-(4-pyridyl)-3-cyano-6-ethyl-4,6-dihydropyrano[3,2-c][2,1] benzothiazine 5,5-dioxide (4b). A white powder. M. p. $-223-225^{\circ} \mathrm{C}$ (decomp.) (from EtOH). Anal. Calcd for $\mathrm{C}_{19} \mathrm{H}_{16} \mathrm{~N}_{4} \mathrm{O}_{3} \mathrm{~S}$ : C, 59.99; $\mathrm{H}, 4.24$; N, 14.73; S, 8.43. Found: C, 60.13; H, 4.57; N, 14.61; S, 8.55. ${ }^{1} \mathrm{H}$ NMR (500 MHz, DMSO- $\mathrm{d}_{6}$ ): $\delta(\mathrm{ppm}) 8.53(\mathrm{~d}$, $J=5.76 \mathrm{~Hz}, 2 \mathrm{H}$ ), $7.94(\mathrm{~d}, J=7.68 \mathrm{~Hz}, 1 \mathrm{H}), 7.61-7.69$ $(\mathrm{t}, J=7.53 \mathrm{~Hz}, 1 \mathrm{H}), 7.55(\mathrm{~d}, J=8.23 \mathrm{~Hz}, 1 \mathrm{H}), 7.47(\mathrm{~s}$, $2 \mathrm{H}), 7.39(\mathrm{t}, J=7.55 \mathrm{~Hz}, 1 \mathrm{H}), 7.32(\mathrm{~d}, J=5.49 \mathrm{~Hz}, 2 \mathrm{H})$, $4.78(\mathrm{~s}, 1 \mathrm{H}), 3.87(\mathrm{q}, J=6.86 \mathrm{~Hz}, 2 \mathrm{H}), 1.03(\mathrm{t}, J=7.00$ $\mathrm{Hz}, 3 \mathrm{H})$.

The general procedure for the synthesis of 2amino-4-heteryl-3-cyano-6-ethyl-4,6-dihydropyrano[3,2-c][2,1]benzothiazine 5,5-dioxides (4c-e).

Method A. The three-component one-pot procedure. To the solution of 1-ethyl-1H-2,1-benzothiazin-4(3H)-one 2,2-dioxide (1) ( $0.225 \mathrm{~g}, 0.001 \mathrm{Mol})$, malononitrile (3) $(0.066 \mathrm{~g}, 0.001 \mathrm{Mol})$ and the corresponding heterylcarbaldehyde (2c-e) (0.001 Mol) in ethanol (5-10 mL) add the catalytic amount of triethylamine. Reflux the mixture obtainted for the time specified in Table 1. After heating cool the mixture to the room temperature. Filter the resulting precipitates of (4c-e), wash with ethanol, then dry on air and recrystallize from ethanol.

Method B. The synthesis using intermediate acrylonitriles ( $5 c-e$ ). To the solution of 1-ethyl-1H-2,1-benzothiazin-4(3H)-one 2,2-dioxide (1) $(0.225 \mathrm{~g}, 0.001 \mathrm{Mol})$ and the corresponding acrylonitrile $(5 \boldsymbol{c}-\boldsymbol{e})(0.001 \mathrm{Mol})$ in ethanol (5-10 mL) add the catalytic amount of triethylamine. Reflux the mixture obtained for the time specified in Table 1. The resulting mixtures are treated as mentioned in Method A.

The yields for the compounds (4c-e) synthesized are presented in Table 1.

2-Amino-4-(2-thienyl)-3-cyano-6-ethyl-4,6-dihydropyrano[3,2-c][2,1] benzothiazine 5,5-dioxide (4c). A light yellow powder. M. p. $-241-243^{\circ} \mathrm{C}$ (decomp.) (from EtOH). Anal. Calcd for $\mathrm{C}_{18} \mathrm{H}_{15} \mathrm{~N}_{3} \mathrm{O}_{3} \mathrm{~S}_{2}: \mathrm{C}, 56.09$; H, 3.92; N, 10.90; S, 16.64. Found: C, 56.13; H, 4.37; N, 10.61; S, $16.55 .{ }^{1} \mathrm{H}$ NMR (500 MHz, DMSO-d $\left.{ }_{6}\right): \delta(\mathrm{ppm})$ $7.94(\mathrm{~d}, J=7.94 \mathrm{~Hz}, 1 \mathrm{H}), 7.31-7.74(\mathrm{~m}, 6 \mathrm{H}), 7.03(\mathrm{~d}$, $J=3.05 \mathrm{~Hz}, 1 \mathrm{H}), 6.89-6.98(\mathrm{~m}, 1 \mathrm{H}), 5.06$ (s, $1 \mathrm{H}), 3.92$ (q, $J=6.72 \mathrm{~Hz}, 2 \mathrm{H}), 1.05(\mathrm{t}, J=6.87 \mathrm{~Hz}, 3 \mathrm{H}$ ).

2-Amino-4-(2-furyl)-3-cyano-6-ethyl-4,6-dihydropyrano[3,2-c][2,1] benzothiazine 5,5-dioxide (4d). A light brown powder. M. p. $-215-217^{\circ} \mathrm{C}$ (decomp.) (from EtOH). Anal. Calcd for $\mathrm{C}_{18} \mathrm{H}_{15} \mathrm{~N}_{3} \mathrm{O}_{4} \mathrm{~S}$ : C, 58.53; H, 4.09; N, 11.38; S, 8.68. Found: C, 58.34; H, 4.01; N, 11.87; S, 8.27. ${ }^{1} \mathrm{H}$ NMR (500 MHz, DMSO-d ${ }_{6}$ ): $\delta(\mathrm{ppm}) 7.90(\mathrm{dd}$, $J=8.09,1.37 \mathrm{~Hz}, 1 \mathrm{H}), 7.64(\mathrm{td}, J=7.70,1.50 \mathrm{~Hz}, 1 \mathrm{H})$, 7.51-7.57 (m, $2 \mathrm{H}), 7.35-7.43(\mathrm{~m}, 3 \mathrm{H}), 6.36$ (dd, $J=3.20$, $1.98 \mathrm{~Hz}, 1 \mathrm{H}), 6.28(\mathrm{~m}, J=3.70 \mathrm{~Hz}, 1 \mathrm{H}), 4.82(\mathrm{~s}, 1 \mathrm{H})$, $3.90(\mathrm{q}, J=7.02 \mathrm{~Hz}, 2 \mathrm{H}), 1.01(\mathrm{t}, J=7.02 \mathrm{~Hz}, 3 \mathrm{H})$.

2-Amino-4-(3-indolyl)-3-cyano-6-ethyl-4,6-dihydropyrano[3,2-c][2,1] benzothiazine 5,5-dioxide (4e). A yellow crystalline powder. M. p. $-212-215^{\circ} \mathrm{C}$ (decomp.) (from EtOH). Anal. Calcd for $\mathrm{C}_{22} \mathrm{H}_{18} \mathrm{~N}_{4} \mathrm{O}_{3} \mathrm{~S}$ : C, 63.14; H, 4.34; N, 13.39; S, 7.66. Found: C, 63.52; H, 4.12; N, 13.75; S, 7.37. ${ }^{1} \mathrm{H}$ NMR (500 MHz, DMSO-d ${ }_{6}$ ): $\delta$ (ppm) 11.02 (br. s., $1 \mathrm{H}), 8.00$ (d, $J=7.96 \mathrm{~Hz}, 1 \mathrm{H})$, $7.63(\mathrm{t}, J=7.33 \mathrm{~Hz}, 1 \mathrm{H}), 7.51(\mathrm{~d}, J=7.96 \mathrm{~Hz}, 1 \mathrm{H})$, 7.29-7.44 (m, 4 H), 7.23 (br. s., 2 H), 7.06 (t, $J=7.14$ $\mathrm{Hz}, 1 \mathrm{H}), 6.93(\mathrm{t}, J=7.14 \mathrm{~Hz}, 1 \mathrm{H}), 4.95(\mathrm{~s}, 1 \mathrm{H}), 3.87$ $(\mathrm{q}, J=6.90 \mathrm{~Hz}, 2 \mathrm{H}), 0.99(\mathrm{t}, J=6.59 \mathrm{~Hz}, 5 \mathrm{H})$.

Procedures for the synthesis of 2-amino-4-heteryl-3-ethoxycarbonyl-6-ethyl-4,6-dihydropyrano[3,2-c][2,1]benzothiazine 5,5-dioxides (7a-d). Compounds (7a-d) were obtained in conditions given below. The yields for the compounds (7a-d) synthesized are presented in Table 2.

The general procedure for the synthesis of 2amino-3-ethoxycarbonyl-4-pyridyl-6-ethyl-4,6-dihydropyrano[3,2-c] $[2,1]$ benzothiazine 5,5 -dioxides $(7 a, b)$.

Method A. The three-component one-pot procedure. To the solution of 1-ethyl-1H-2,1-benzothiazin-4(3H)-one 2,2-dioxide (1) $(0.225 \mathrm{~g}, 0.001 \mathrm{Mol})$, ethyl cyanoacetate (6) $(0.11 \mathrm{~mL}, 0.001 \mathrm{Mol})$ and pyridylcarbaldehydes $(2 \mathbf{a}, \mathbf{b})(0.001 \mathrm{Mol})$ in ethanol $(5 \mathrm{~mL})$ add the catalytic amount of triethylamine. Reflux the mixture for $7 \mathrm{~h}$ and cool to the room temperature. Filter the precipitates of $(\mathbf{7 a}, \mathbf{b})$ formed, wash with cold ethanol, dry on air and recrystallize from ethanol.

Method B. The synthesis using ethyl 2-cyanoacrylates $(\mathbf{9 a}, \mathbf{b})$. To the solution of 1-ethyl-1H-2,1-benzothiazin- $4(3 H)$-one 2,2-dioxide (1) $(0.225 \mathrm{~g}, 0.001 \mathrm{Mol})$ and heterylidenes $(\mathbf{9 a}, \mathbf{b})(0.001 \mathrm{Mol})$ in ethanol $(5 \mathrm{~mL})$ add the catalytic amount of triethylamine. Reflux the solution for $7 \mathrm{~h}$. The resulting reaction mixtures are treated as mentioned in Method A.

2-Amino-4-(3-pyridyl)-3-ethoxycarbonyl-6ethyl-4,6-dihydropyrano[3,2-c][2,1] benzothiazine 5,5-dioxide (7a). A white powder. M. p. $-179-181^{\circ} \mathrm{C}$ (decomp.) (from EtOH). Anal. Calcd for $\mathrm{C}_{21} \mathrm{H}_{21} \mathrm{~N}_{3} \mathrm{O}_{5} \mathrm{~S}$ : C, 59.00; H, 4.95; N, 9.83; S, 7.50. Found: C, 58.75; H, 5.22; N, 9.54; S, 7.19. ${ }^{1} \mathrm{H}$ NMR (500 MHz, DMSO-d ${ }_{6}$ ): $\delta(\mathrm{ppm}) 8.43(\mathrm{~d}, J=1.96 \mathrm{~Hz}, 1 \mathrm{H}), 8.35(\mathrm{dd}, J=4.77$, $1.34 \mathrm{~Hz}, 1 \mathrm{H}$ ), 8.03 (dd, $J=7.95,1.34 \mathrm{~Hz}, 1 \mathrm{H}$ ), 7.87 (s, $2 \mathrm{H}), 7.60-7.66(\mathrm{~m}, 1 \mathrm{H}), 7.51-7.58(\mathrm{~m}, 2 \mathrm{H}), 7.39$ $(\mathrm{t}, J=7.58 \mathrm{~Hz}, 1 \mathrm{H}), 7.26(\mathrm{dd}, J=7.95,4.77 \mathrm{~Hz}, 1 \mathrm{H})$, $4.84(\mathrm{~s}, 1 \mathrm{H}), 3.93-4.00(\mathrm{~m}, 2 \mathrm{H}), 3.87$ (q, $J=7.01$ $\mathrm{Hz}, 2 \mathrm{H}), 1.06(\mathrm{t}, J=7.09 \mathrm{~Hz}, 3 \mathrm{H}), 0.96(\mathrm{t}, J=6.97$ $\mathrm{Hz}, 3 \mathrm{H})$. 
2-Amino-4-(4-pyridyl)-3-ethoxycarbonyl-6ethyl-4,6-dihydropyrano[3,2-c][2,1] benzothiazine 5,5-dioxide (7b). Red crystalls. M. p. $-168-170^{\circ} \mathrm{C}$ (decomp.) (from EtOH). Anal. Calcd for $\mathrm{C}_{21} \mathrm{H}_{21} \mathrm{~N}_{3} \mathrm{O}_{5} \mathrm{~S}$ : C, 59.00; H, 4.95; N, 9.83; S, 7.50. Found: C, 58.51; H, 5.38; N, 9.73; S, 7.39. ${ }^{1} \mathrm{H}$ NMR (500 MHz, DMSO-d ${ }_{6}$ ): $\delta$ (ppm) 8.42-8.46 (m, $2 \mathrm{H}$ ), 8.03 (dd, $J=8.07,1.22$ $\mathrm{Hz}, 1 \mathrm{H}), 7.90(\mathrm{~s}, 2 \mathrm{H}), 7.60-7.67(\mathrm{~m}, 1 \mathrm{H}), 7.54(\mathrm{~d}$, $J=8.31 \mathrm{~Hz}, 1 \mathrm{H}), 7.39(\mathrm{t}, J=7.70 \mathrm{~Hz}, 1 \mathrm{H}), 7.18-7.22$ $(\mathrm{m}, 2 \mathrm{H}), 4.83(\mathrm{~s}, 1 \mathrm{H}), 3.93-4.02(\mathrm{~m}, 2 \mathrm{H}), 3.87(\mathrm{q}$, $J=7.01 \mathrm{~Hz}, 2 \mathrm{H}), 1.08(\mathrm{t}, J=7.09 \mathrm{~Hz}, 3 \mathrm{H}), 0.98(\mathrm{t}$, $J=6.97 \mathrm{~Hz}, 3 \mathrm{H}$ ).

The synthesis of 2-amino-3-ethoxycarbonyl-4(2-thienyl)-6-ethyl-4,6-dihydropyrano[3,2-c][2,1] benzothiazine 5,5-dioxide (7c). To the solution of 1-ethyl-1H-2,1-benzothiazin-4(3H)-one 2,2-dioxide (1) $(0.225 \mathrm{~g}, 0.001 \mathrm{Mol})$, ethyl cyanoacetate $(6)(0.77 \mathrm{~mL}$, $0.007 \mathrm{Mol})$ and thiophen-2-carbaldehyde $2 \mathrm{c}(0.94 \mathrm{~mL}$, $0.001 \mathrm{Mol})$ in ethanol $(5 \mathrm{~mL})$ add the catalytic amount of triethylamine. . Reflux the mixture for $8 \mathrm{~h}$, cool to the room temperature. Filter the precipitate $\mathbf{7} \mathbf{c}$ formed, wash with cold ethanol, dry on air and recrystallize from ethanol.

Light yellow crystalls. M. p. $-185-187^{\circ} \mathrm{C}$ (decomp.) (from EtOH). Anal. Calcd for $\mathrm{C}_{20} \mathrm{H}_{20} \mathrm{~N}_{2} \mathrm{O}_{5} \mathrm{~S}_{2}: \mathrm{C}, 55.54$; $\mathrm{H}, 4.66$; N, 6.48; S, 14.83. Found: C, 55.81; H, 4.93; N, 6.82; S, 15.04. ${ }^{1} \mathrm{H}$ NMR (500 MHz, DMSO-d 6 ): $\delta(\mathrm{ppm})$ 8.02 (d, $J=7.93 \mathrm{~Hz}, 1 \mathrm{H}$ ), 7.82 (br. s., $2 \mathrm{H}$ ), 7.59-7.67 $(\mathrm{m}, 1 \mathrm{H}), 7.55(\mathrm{~d}, J=8.24 \mathrm{~Hz}, 1 \mathrm{H}), 7.37(\mathrm{t}, J=7.63 \mathrm{~Hz}$, $1 \mathrm{H}), 7.21-7.27(\mathrm{~m}, 1 \mathrm{H}), 6.82-6.88(\mathrm{~m}, 2 \mathrm{H}), 5.17(\mathrm{~s}, 1 \mathrm{H})$, $4.02-4.11(\mathrm{~m}, 2 \mathrm{H}), 3.94(\mathrm{q}, J=6.82 \mathrm{~Hz}, 2 \mathrm{H}), 1.16(\mathrm{t}$, $J=6.90 \mathrm{~Hz}, 3 \mathrm{H}), 1.04(\mathrm{t}, J=7.00 \mathrm{~Hz}, 3 \mathrm{H})$.

The synthesis of 2-amino-3-ethoxycarbonyl-4(2-furyl)-6-ethyl-4,6-dihydropyrano[3,2-c][2,1] benzothiazine 5,5-dioxide (7d). To the solution of 1-ethyl-1H-2,1-benzothiazin-4(3H)-one 2,2-dioxide (1) $(0.225 \mathrm{~g}, 0.001 \mathrm{Mol})$, ethyl cyanoacetate $(6)(0.11 \mathrm{~mL}$, $0.001 \mathrm{Mol})$ and furan-2-carbaldehyde $2 \mathbf{d}(0.83 \mathrm{~mL}$, $0.001 \mathrm{Mol})$ in ethanol ( $5 \mathrm{~mL}$ ) add the catalytic amount of triethylamine. Reflux the mixture for $10 \mathrm{~h}$, cool to the room temperature. Filter the precipitate of $\mathbf{7} \mathbf{c}$ formed, wash with cold ethanol, dry on air and recrystallize from ethanol.

Colourless crystalls. M. p. $-169-171^{\circ} \mathrm{C}$ (decomp.) (from EtOH). Anal. Calcd for $\mathrm{C}_{20} \mathrm{H}_{20} \mathrm{~N}_{2} \mathrm{O}_{6} \mathrm{~S}$ : C, 57.68; H, 4.84; N, 6.73; S, 7.70. Found: C, 57.94; H, 4.50; N, 6.31; $\mathrm{S}, 7.83 .{ }^{1} \mathrm{H}$ NMR (500 MHz, DMSO-d ${ }_{6}$ ): $\delta(\mathrm{ppm})$ 7.99 (d, J=8.07 Hz, $1 \mathrm{H}$ ), 7.80 (br. s., $2 \mathrm{H}), 7.63$ (t, $J=7.30 \mathrm{~Hz}, 1 \mathrm{H}), 7.54(\mathrm{~d}, J=8.31 \mathrm{~Hz}, 1 \mathrm{H}), 7.32-7.44$ (m, 2 H), 6.29 (br. s., 1 H), 6.12 (br. s., 1 H), 4.97 (s, 1 H), 4.00-4.10 (m, $2 \mathrm{H}), 3.92(\mathrm{~d}, J=6.85 \mathrm{~Hz}, 2 \mathrm{H}), 1.14(\mathrm{t}$, $J=6.97 \mathrm{~Hz}, 3 \mathrm{H}$ ), 0.98 (t, $J=6.72 \mathrm{~Hz}, 3 \mathrm{H}$ ).

Procedures for the synthesis of triethylammonium 3-[(4-hydroxy-1-ethyl-2,2-dioxido-1H-2,1benzothiazin-3-yl)(heteryl)methyl]-1-ethyl1H-2,1-benzothiazin-5-olat 2,2-dioxides (8a-e). These products were obtained using the procedures described below. The yields for compounds (8a-e) synthesized are presented in Table 3.

The synthesis of triethylammonium 3-[(4-hydroxy-1-ethyl-2,2-dioxido-1H-2,1-benzothiazin3-yl)(3-piridyl)methyl]-1-ethyl-1H-2,1-benzo thiazin-5-olat 2,2-dioxide (8a). To the solution of 1-ethyl-1H-2,1-benzothiazin-4(3H)-one 2,2-dioxide (1) $(0.450 \mathrm{~g}, 0.002 \mathrm{Mol})$, piridin-3-carbaldehyde (2a) $(0.094 \mathrm{~mL}, 0.001 \mathrm{Mol})$ in ethanol $(10 \mathrm{~mL})$ add triethylamine $(0.14 \mathrm{~mL}, 0.001 \mathrm{Mol})$. Stir the solution at the room temperature. In about $1 \mathrm{~h}$ a white precipitate of (8a) is formed, filter it, wash with ethanol, dry on air and recrystallize from ethanol.

A white powder. M. p. $-168-170^{\circ} \mathrm{C}$ (decomp.) (from EtOH). Anal. Calcd for $\mathrm{C}_{32} \mathrm{H}_{40} \mathrm{~N}_{4} \mathrm{O}_{6} \mathrm{~S}_{2}$ : C, 59.98; $\mathrm{H}, 6.29$; N, 8.74; S, 10.01. Found: C, 59.71; H, 6.52; N, 9.12; S, 10.19. ${ }^{1} \mathrm{H}$ NMR (500 MHz, DMSO-d ${ }_{6}$ ): $\delta(\mathrm{ppm}) 17.19$ $(\mathrm{s}, 1 \mathrm{H}), 8.38(\mathrm{~d}, J=0.73 \mathrm{~Hz}, 1 \mathrm{H}), 8.24-8.29(\mathrm{~m}, 1 \mathrm{H})$, 7.83-7.88 (m, $2 \mathrm{H}), 7.54$ (d, $J=8.07 \mathrm{~Hz}, 1 \mathrm{H}), 7.40-7.46$ $(\mathrm{m}, 2 \mathrm{H}), 7.29(\mathrm{~d}, J=8.31 \mathrm{~Hz}, 2 \mathrm{H}), 7.20(\mathrm{dd}, J=7.95$, $4.77 \mathrm{~Hz}, 1 \mathrm{H}), 7.12(\mathrm{t}, J=7.58 \mathrm{~Hz}, 2 \mathrm{H}), 5.73(\mathrm{~s}, 1 \mathrm{H})$, $3.95(\mathrm{q}, J=7.09 \mathrm{~Hz}, 4 \mathrm{H}), 2.98-3.08(\mathrm{~m}, 6 \mathrm{H}), 1.19(\mathrm{t}$, $J=6.97 \mathrm{~Hz}, 6 \mathrm{H}), 1.11(\mathrm{td}, J=7.28,1.34 \mathrm{~Hz}, 9 \mathrm{H})$.

The synthesis of triethylammonium 3-[(4-hydroxy-1-ethyl-2,2-dioxido-1 $H$-2,1-benzothiazin3-yl)(pirid-4-yl)methyl]-1-ethyl-1H-2,1-benzothiazin-5-olat 2,2-dioxide (8b). To the solution of 1-ethyl-1H-2,1-benzothiazin-4(3H)-one 2,2-dioxide (1) $(0.450 \mathrm{~g}, 0.002 \mathrm{Mol})$, piridin-4-carbaldehyde (2a) $(0.094 \mathrm{~mL}, 0.001 \mathrm{Mol})$ in ethanol $(10 \mathrm{~mL})$ add triethylamine $(0.14 \mathrm{~mL}, 0.001 \mathrm{Mol})$. Reflux the mixture for $2 \mathrm{~h}$, cool to the room temperature and dilute with water. Then the precipitate of $(\mathbf{8 b})$ is formed under intensive stirring. Filter it, wash with water, dry on air and recrystallize from aqueous ethanol.

A light rose powder. M. p. $-170-172^{\circ} \mathrm{C}$ (decomp.) (from EtOH). Anal. Calcd for $\mathrm{C}_{58} \mathrm{H}_{65} \mathrm{~N}_{7} \mathrm{O}_{12} \mathrm{~S}_{4}$ : C, 59.01; $\mathrm{H}, 5.55 ; \mathrm{N}, 8.31 ; \mathrm{S}, 10.87$. Found: C, 59.37; H, 5.31; N, 8.78; S, 10.52. ${ }^{1} \mathrm{H}$ NMR (500 MHz, DMSO-d ${ }_{6}$ ): $\delta(\mathrm{ppm})$ 17.13 (s, $2 \mathrm{H}), 8.31-8.38$ (m, $4 \mathrm{H}), 7.85$ (dd, $J=7.95$, $1.59 \mathrm{~Hz}, 4 \mathrm{H}), 7.39-7.47(\mathrm{~m}, 4 \mathrm{H}), 7.30(\mathrm{~d}, J=8.31 \mathrm{~Hz}$, $4 \mathrm{H}), 7.18(\mathrm{~d}, J=4.89 \mathrm{~Hz}, 4 \mathrm{H}), 7.12(\mathrm{t}, J=7.58 \mathrm{~Hz}, 4 \mathrm{H})$, $5.66(\mathrm{~s}, 2 \mathrm{H}), 3.95(\mathrm{qd}, J=7.05,2.32 \mathrm{~Hz}, 8 \mathrm{H}), 3.02(\mathrm{q}$, $J=7.34 \mathrm{~Hz}, 6 \mathrm{H}), 1.20(\mathrm{t}, J=6.97 \mathrm{~Hz}, 12 \mathrm{H}), 1.11(\mathrm{t}$, $J=7.21 \mathrm{~Hz}, 9 \mathrm{H})$.

The synthesis of triethylammonium 3-[(4-hydroxy-1-ethyl-2,2-dioxido-1H-2,1-benzothiazin3-yl)(thien-2-yl)methyl]-1-ethyl-1H-2,1-benzothiazin-5-olat 2,2-dioxide (8c).

Method A. To the solution of 1-ethyl-1H-2,1-benzothiazin-4(3H)-one 2,2-dioxide (1) $(0.225 \mathrm{~g}, 0.001 \mathrm{Mol})$, ethyl cyanoacetate $(6)(0.11 \mathrm{~mL}, 0.001 \mathrm{Mol})$ and thiophen-2-carbaldehyde (2c) $(0.094 \mathrm{~mL}, 0.001 \mathrm{Mol})$ in ethanol $(10 \mathrm{~mL})$ add the catalytic amount of triethylamine. Reflux the mixture for $8 \mathrm{~h}$, cool to the room temperature. Filter the precipitate of (8c), wash with cold ethanol, dry on air and recrystallize from ethanol. 
Method B. To the solution of 1-ethyl-1H-2,1-benzothiazin-4(3H)-one 2,2-dioxide (1) $(0.225 \mathrm{~g}, 0.001 \mathrm{Mol})$ and ethyl 2-cyano-3-(thiophen-2-yl)acrylate (9c) (0.207g, $0.001 \mathrm{Mol})$ in ethanol $(10 \mathrm{~mL})$ add the catalytic amount of triethylamine. Reflux the mixture for $8 \mathrm{~h}$, cool to the room temperature and keep at this temperature until the precipitate of $(\mathbf{8 c})$ is formed, wash with cold ethanol, dry on air and recrystallize from ethanol.

Method $C$. To the solution of 1-ethyl-1H-2,1-benzothiazin-4(3H)-one 2,2-dioxide (1) $(0.450 \mathrm{~g}, 0.002 \mathrm{Mol})$, thiophen-2-carbaldehyde (2c) $(0.094 \mathrm{~mL}, 0.001 \mathrm{Mol})$ in ethanol $(10 \mathrm{~mL})$ add triethylamine $(0.14 \mathrm{~mL}, 0.001 \mathrm{Mol})$. Allow the solution to stand overnight at the room temperature. When the light yellow crystalline precipitate of (8c) is formed; filter it, wash with ethanol, dry on air and recrystallize from ethanol.

Light yellow crystalls. M. p. $-158-160^{\circ} \mathrm{C}$ (decomp.) (from EtOH). Anal. Calcd for $\mathrm{C}_{31} \mathrm{H}_{39} \mathrm{~N}_{3} \mathrm{O}_{6} \mathrm{~S}_{3}$ : C, 57.65; $\mathrm{H}, 6.09 ; \mathrm{N}, 6.51 ; \mathrm{S}, 14.89$. Found: $\mathrm{C}, 57.91 ; \mathrm{H}, 5.73 ; \mathrm{N}$, 6.84; S, 14.55. ${ }^{1} \mathrm{H}$ NMR (500 MHz, DMSO-d 6 ): $\delta(\mathrm{ppm})$ 17.49 (s, $1 \mathrm{H}$ ), 7.88 (dd, $J=7.93,1.53 \mathrm{~Hz}, 2 \mathrm{H}$ ), 7.38-7.45 $(\mathrm{m}, 2 \mathrm{H}), 7.28(\mathrm{~d}, J=7.93 \mathrm{~Hz}, 2 \mathrm{H}), 7.08-7.16(\mathrm{~m}, 3 \mathrm{H})$, $6.74(\mathrm{dd}, J=5.04,3.51 \mathrm{~Hz}, 1 \mathrm{H}), 6.63-6.68(\mathrm{~m}, 1 \mathrm{H})$, $5.82(\mathrm{~s}, 1 \mathrm{H}), 3.86-3.98(\mathrm{~m}, 4 \mathrm{H}), 3.02(\mathrm{q}, J=7.32 \mathrm{~Hz}$, $6 \mathrm{H}), 1.18(\mathrm{t}, J=7.02 \mathrm{~Hz}, 6 \mathrm{H}), 1.11(\mathrm{t}, J=7.32 \mathrm{~Hz}, 9 \mathrm{H})$.

The synthesis of triethylammonium 3-[(4-hydroxy-1-ethyl-2,2-dioxido-1H-2,1-benzothiazin-3-yl) (fur-2-yl)methyl]-1-ethyl-1H-2,1-benzothiazin-5olat 2,2-dioxide (8d). To the solution of 1-ethyl- $1 H$ 2,1-benzothiazin-4(3H)-one 2,2-dioxide (1) $(0.450 \mathrm{~g}$, $0.002 \mathrm{Mol})$, furan-2-carbaldehyde (2d) $(0.083 \mathrm{~mL}$, $0.001 \mathrm{Mol})$ in ethanol $(10 \mathrm{~mL})$ add triethylamine $(0.14 \mathrm{~mL}$, $0.001 \mathrm{Mol})$. Stir the solution at the room temperature for $7 \mathrm{~h}$ and cool to $0^{\circ} \mathrm{C}$. Filter the light yellow crystalline precipitate of (8d) formed, wash with ethanol, dry on air and recrystallize from ethanol.

Light yellow crystalls. M. p. $-142-144^{\circ} \mathrm{C}$ (decomp.) (from EtOH). Anal. Calcd for $\mathrm{C}_{31} \mathrm{H}_{39} \mathrm{~N}_{3} \mathrm{O}_{7} \mathrm{~S}_{2}: \mathrm{C}, 59.12$; $\mathrm{H}, 6.24 ; \mathrm{N}, 6.67 ; \mathrm{S}, 10.18$. Found: $\mathrm{C}, 59.41 ; \mathrm{H}, 6.37 ; \mathrm{N}$, 6.88; S, 10.53. ${ }^{1} \mathrm{H}$ NMR (500 MHz, DMSO-d $\left.{ }_{6}\right): \delta(\mathrm{ppm})$ $17.34(\mathrm{~s}, 1 \mathrm{H}), 7.87(\mathrm{dd}, J=7.87,1.21 \mathrm{~Hz}, 2 \mathrm{H}), 7.38-7.44$ (m, $2 \mathrm{H}), 7.25-7.31(\mathrm{~m}, 3 \mathrm{H}), 7.13(\mathrm{t}, J=7.42 \mathrm{~Hz}, 2 \mathrm{H})$, $6.20(\mathrm{dd}, J=2.88,1.97 \mathrm{~Hz}, 1 \mathrm{H}), 5.94-5.98(\mathrm{~m}, 1 \mathrm{H})$, $5.62(\mathrm{~s}, 1 \mathrm{H}), 3.82-3.92(\mathrm{~m}, 4 \mathrm{H}), 3.03(\mathrm{q}, J=7.27 \mathrm{~Hz}$, $6 \mathrm{H}), 1.13(\mathrm{q}, J=7.17 \mathrm{~Hz}, 15 \mathrm{H})$.
The synthesis of triethylammonium 3-[(4-hydroxy-1-ethyl-2,2-dioxido-1H-2,1-benzothiazin-3-yl) (indol-3-yl)methyl]-1-ethyl-1H-2,1-benzothiazin5-olat 2,2-dioxide (8e). To the solution of 1-ethyl1H-2,1-benzothiazin-4(3H)-one 2,2-dioxide (1) $(0.450 \mathrm{~g}$, $0.002 \mathrm{Mol})$, indol-3-carbaldehyde (2e) $(0.145 \mathrm{~g}, 0.001 \mathrm{Mol})$ in ethanol $(10 \mathrm{~mL})$ add triethylamine $(0.14 \mathrm{~mL}, 0.001 \mathrm{Mol})$. Reflux the mixture for $12 \mathrm{~h}$, cool to the room temperature and dilute with water. Filter the precipitate of (8e) formed, wash with water, dry on air and recrystallize from aqueous ethanol.

A yellow powder. M. p. $-105-107^{\circ} \mathrm{C}$ (decomp.) (from EtOH). Anal. Calcd for $\mathrm{C}_{35} \mathrm{H}_{42} \mathrm{~N}_{4} \mathrm{O}_{6} \mathrm{~S}_{2}$ : C, 61.92; H, 6.24; N, 8.25; S, 9.45. Found: C, 61.74; H, 6.41; N, 8.57; S, 9.35. ${ }^{1} \mathrm{H}$ NMR (500 MHz, DMSO-d 6 ): $\delta(\mathrm{ppm})$ $17.48(\mathrm{~s}, 1 \mathrm{H}), 10.51(\mathrm{~s}, 1 \mathrm{H}), 7.86(\mathrm{~d}, J=7.93 \mathrm{~Hz}, 2 \mathrm{H})$, 7.55-7.59 (m, $1 \mathrm{H}), 7.34-7.40$ (m, $2 \mathrm{H}), 7.17-7.26$ (m, $3 \mathrm{H}), 7.07(\mathrm{t}, J=7.63 \mathrm{~Hz}, 2 \mathrm{H}), 7.01(\mathrm{~d}, J=1.22 \mathrm{~Hz}, 1 \mathrm{H})$, $6.88(\mathrm{t}, J=7.63 \mathrm{~Hz}, 1 \mathrm{H}), 6.71(\mathrm{t}, J=7.48 \mathrm{~Hz}, 1 \mathrm{H}), 5.91$ (s, $1 \mathrm{H}), 3.90-4.00(\mathrm{~m}, 4 \mathrm{H}), 2.92(\mathrm{q}, J=7.12 \mathrm{~Hz}, 6 \mathrm{H})$, $1.19(\mathrm{t}, J=7.02 \mathrm{~Hz}, 6 \mathrm{H}), 1.08(\mathrm{t}, J=7.32 \mathrm{~Hz}, 9 \mathrm{H})$.

\section{Conclusions}

Some peculiarities of the three-component interaction of 1-ethyl-1H-2,1-benzothiazin-4(3H)-one 2,2dioxide with malononitrile and different heterylcarbaldehydes have been studied and described.

In the case of malononitrile the three-component condensation provides exclusively formation of 2amino-3-cyano- $4 H$-pyranes in high yields. When ethyl cyanoacetate is used, the interaction results in formation of three different products depending on the heteryl fragment in the initial aldehyde, namely the expected 2-amino-3-ethoxycarbonyl- $4 \mathrm{H}$-pyranes, the triethylammonium salt of bis-adducts or ethyl 2-cyanoacrylates.

The modified mechanism for the synthesis of 2amino- $4 \mathrm{H}$-pyranes has been proposed. It has allowed to synthesize selectively 2-aminopyranes and avoid formation of the triethylammonium salt of bis-adducts.

A purposeful synthesis of the triethylammonium salt of bis-adducts has been performed by the interaction of 1-ethyl-1H-2,1-benzothiazin-4(3H)-one 2,2-dioxide with heterylcarbaldehydes in the presence of triethylamine.

\section{References}

1. Hicks J. L., Roark W. H. WO2004014388A1, 2004.

2. Hu Q.-Y., Ksander G. M. WO2008076860A1, 2008.

3. Nie H., Widdowson K. L. WO 9834929, 1998.

4. Catsoulacos P., Camoutsis C. J. Heterocycl. Chem., 1979, Vol. 23, No.8, pp.1503-1524.

5. Muegge I. Medicinal Research Reviews, 2003, Vol. 23, No.3, pp.302-321.

6. Supuran C. T., Casini A., Scozzafava A. Medicinal Research Reviews, 2003, Vol. 23, No.5, pp.535-558.

7. Hanson P. R., Probst D. A., Robinson R. E., Yau M. Tetrahedron Lett., 1999, Vol. 40, No.26, pp.4761-4764.

8. Moree W. J., van der Marel G. A., Liskamp R. M. J. Tetrahedron Lett., 1991, Vol. 32, No.3, pp.409-412.

9. Harmata M., Calkins N. L., Baughman R. G., Barnes C. L. J. Org. Chem., 2006, Vol. 71, No.9, pp.3650-3652.

10. Misu Y., Togo H. Org. Biomol. Chem., 2003, Vol. 1, No.8, pp.1342-1346.

11. Fairhurst J., Gallagher P. WO 2001087881, 2001.

12. Li W., Marlowe C. K., Scarborough R. M. WO 2001072725, 2001.

13. Yoakim C., O’Meara J., Simoneau B., Ogilie W. W., Deziel R. WO 2004026875, 2004. 
14. Pieroni M., Sabatini S., Massari S., Kaatz G. W., Cecchetti V., Tabarrini O. Med. Chem. Commun., 2012, Vol. 3, No.9, pp.1092-1097.

15. Ukrainets I. V., Petrushova L. A., Dzyubenko S. P., Liu Y. Chem. Heterocycl. Compd. (N. Y., NY, U. S.), 2014, Vol. 50, No.4, pp.564-572.

16. Loev B., Kormendy M. F., Snader K. M. J. Org. Chem., 1966, Vol. 31, No.11, pp.3531-3534.

17. Lombardino J. G. J. Heterocycl. Chem., 1972, Vol. 9, No.2, pp.315-317.

18. Coppo F. T., Fawzi M. M. J. Heterocycl. Chem., 1998, Vol. 35, No.4, pp.983-987.

19. Shemchuk L. A., Lega D. A., Redkin R. G., Chernykh V. P., Shishkin O. V., Shishkina S. V. Tetrahedron, 2014, Vol. 70, No.44, pp.8348-8353.

20. Amirnejad M., Naimi-Jamal M. R., Tourani H., Ghafuri H. Monatsh. Chem., 2013, Vol. 144, No.8, pp.1219-1225.

21. Brahmachari G., Banerjee B. ACS Sustainable Chemistry \& Engineering, 2013, Vol. 2, No.3, pp.411-422.

22. Shaterian H. R., Arman M., Rigi F. J. Mol. Liq., 2011, Vol. 158, No.2, pp.145-150.

23. Patel V. K., Sen D. J., Patel C. N. J. Chem. Pharm. Res., 2010, Vol. 2, No.2, pp.50-56.

24. Zanwar M. R., Raihan M. J., Gawande S. D., Kavala V., Janreddy D., Kuo C.-W., Ambre R., Yao C.-F. J. Org. Chem., 2012, Vol. 77, No.15, pp.6495-6504.

25. Redkin R. G., Shemchuk L. A., Chernykh V. P., Shishkin O. V., Shishkina S. V. Tetrahedron, 2007, Vol. 63, No.46, pp.11444-11450.

Надійшла до редакції 22.12.2015 р. 